\title{
Herbaria century record of increasing eutrophication in Spanish terrestrial ecosystems
}

\author{
J OSEP PEÑUELAS*+ and I OLANDA FILELLA* \\ ${ }^{*}$ CREAF (Center for Ecological Research and Forestry Applications), Facultat de Ciències, Universitat Autònoma de Barcelona, \\ 08193 Bellaterra (Barcelona), Spain, +IBMB, CSIC (Consejo Superior de Investigaciones Científicas), Jordi Girona 18-26, \\ 08034 Barcelona, Spain
}

\begin{abstract}
Additional biological evidence is presented for the alteration of biogeochemical cycles by human activities. The leaf $\delta^{15} \mathrm{~N}$ and the concentrations of nutrients in herbarium specimens of 24 species of vascular plants and 3 species of bryophytes collected in northern and eastern regions of Spain have substantially changed throughout the XX century. In the second half of the century, when anthropogenic nitrogen fixation and mobilization started to increase rapidly, leaf $\delta^{15} \mathrm{~N}$ values started to decrease strongly, indicating that additional anthropogenic nitrogen is being retained in Spanish terrestrial ecosystems. The concentration of nutrients in vascular plants did not present any clear pattern, but there were increasing concentrations of $N$ and other nutrients $(P, K$, and $S$ ) in the last decades in bryophytes, which are usually better biomonitors of airborne chemicals than vascular plants. Important consequences for ecosystem structure and functioning such as enhancement of the carbon sink or changes in community biodiversity and species distribution may be expected from this increase in eutrophication.
\end{abstract}

Keywords: bryophytes, $\delta^{15} \mathrm{~N}$, nitrogen, nutrients, vascular plants

Received 9 September 2000; revised version received and accepted 27 November 2000

\section{Introduction}

Global biogeochemical cycles are being altered strongly by anthropic activities. The global $\mathrm{N}$ cycle has now reached the point where more $\mathrm{N}$ is fixed annually by human-driven processes (fertilisers, combustion of fossil fuels, legume crops) than by natural ones (Vitousek et al. 1997). In addition to fixing nitrogen, human activity mobilizes nitrogen from long-term storage pools through biomass burning, land clearing and conversion, and drainage of wetlands (Crutzen \& Andreae 1990; Vitousek et al. 1997). Both newly fixed and mobilized nitrogen can be transported in solution or in the atmosphere and thus alterations to the $\mathrm{N}$ cycle can spread regionally and globally. Such an enormous increase in the eutrophication by biologically available forms of this often-limiting nutrient will affect species composition and ecosystem functioning (Melillo etal. 1993; Vitousek etal. 1997). Similar reasoning can be applied to the concentrations of other nutrients such as phosphorus emitted from industrial activities, detergent production and agricul-

Correspondence: J. Peñuelas, fax: +34/ 93 5811312, e-mail penuelas@uab.es ture, or sulphur emitted from coal and residual fuel oil combustion. Their emissions have increased in Europe throughout the century up to the 1980s (European Environment Agency 1998).

Because of their capacity to act as efficient interceptors and accumulators of chemicals, plants are used widely as passive biomonitors in urban and rural environments (Jones et al. 1992; Markert 1993; Monaci \& Bargagli 1997). Among plants, bryophytes are being used increasingly as biomonitors of airborne chemicals (Rühling 1994). Because they lack a root system, they are dependent on the aerial environment to which they are exposed for the uptake of chemical substances. Moreover, they lack a cuticle and epidermis and an active mechanism to mobilize chemicals. These traits facilitate chemical penetration and the integration of temporal fluctuations of chemicals in the environment.

With the aim of studying possible plant chemistry changes in response to the huge input of anthropogenic nutrients into the biosphere, herbarium specimens of 24 species of vascular plants and 3 species of bryophytes collected throughout the XX century in Spain were 
analysed. In order to determine whether there was a huge input of anthropogenic nitrogen, and if so, whether the additional anthropogenic nitrogen was retained in terrestrial ecosystems or lost by denitrification to $\mathrm{N}_{2}$, volatilization of nitrogen oxides and ammonia, or lixiviation to aquatic systems, leaf $\delta^{15} \mathrm{~N}$ and $\mathrm{N}$ concentration were analysed in the herbarium specimens. As the $\delta^{15} \mathrm{~N}$ value of a plant sample is determined primarily by the isotope ratio of the nitrogen source (Nadelhoffer \& Fry 1994; Peñuelas \& Estiarte 1997), especially when the $\mathrm{N}$ supply rate is low in relation to plant demand (Högberg etal. 1999) as it is the case in Spanish ecosystems (Rodà etal. 2000), leaf $\delta^{15} \mathrm{~N}$ was used to make inferences on the $\mathrm{N}$ source and on the relative activity of the different processes of the $\mathrm{N}$ cycle (supplies, retention, and losses) in the surrounding system. Long-term measurements of precipitation nitrogen in Europe, Africa and North America suggest that both ammonium and nitrate inputs to terrestrial ecosystems are relatively depleted in ${ }^{15} \mathrm{~N}$, with values for these inputs ranging from roughly $-10-0 \%$ (Nadelhoffer \& Fry 1994). The $\delta^{15} \mathrm{~N}$ in nitrate from alpine and polar ice cores has been found to decrease together with increasing nitrate concentrations after 1950, when anthropogenic emissions of nitrogen started to increase rapidly in the Northern Hemisphere (Freyer et al. 1996). Based on these facts, it was hypothesized that the increase of anthropogenic $\mathrm{N}$ inputs would be translated into a decrease of plant $\delta^{15} \mathrm{~N}$, especially if this $\mathrm{N}$ is retained instead of being lost from terrestrial ecosystems. The $\mathrm{P}, \mathrm{K}$ and $\mathrm{S}$ concentrations of the herbarium specimens were measured to test whether ecosystem inputs of other nutrients from fossil fuel combustion, fertilisers, industrial sources, or urban wastewater (e.g. detergents) were also increasing.

\section{Materials and methods}

\section{Herbarium specimens}

The vascular plants studied were: Acer opalus, Arbutus unedo, Borago officinalis, Cistus albidus, Chenopodium ambrosoides, Erica multiflora, Fagus sylvatica, Fraxinus excelsior, Hedera helix, Juniperus oxycedrus, Laurus nobilis, Lonicera implexa, Phillyrea angustifolia, Pinus sylvestris, Plantago major, Populus alba, Quercus coccifera, Q. ilex, Rhamnus alaternus, Rhododendron ferrugineum, Rosmarinus officinalis, Ruscus aculeatus, Salvia officinalis, and Thymus vulgaris; and the bryophytes studied were Grimmia laevigata, Hypnum cupressiforme, and Pleurochaete squarro$s a$. Leaves had been stored in the herbaria of the 'Unitat de Botànica de la Facultat de Farmàcia de la Universitat de Barcelona' and the 'Unitat de Botànica de la Universitat Autònoma de Barcelona'. The studied her- barium specimens were collected in Spain (mostly northeastern rural regions). The older specimens had been fumigated with DDT and most specimens had been submitted to temporary freezing temperatures as conservation procedures. Material was sampled from four different decades; for the most recent one specimens already collected and stored for more than 5 years were sampled in order to avoid possible disturbances by initial processes of decomposition. The same locations and seasons for each species were sampled throughout the studied periods. When no samples from the same location could be found throughout the century in the herbarium collections, the closest possible geographical location was sampled. Leaves from the same terminal position of the herbarium specimen were analysed to avoid, as much as possible, variability resultinf from leaf age, position and growth light environment of the collected herbarium specimens. Analyses from 1 to 10 different herbarium specimens were conducted for each vascular plant species at each sampling decade (Table 1). Analyses from 4 to 9 different herbarium specimens were conducted for each bryophyte species at each sampling decade (Table 2). Each analysis was conducted with 3-6 bulked leaves (40-60 for bryophytes) of the same stage of development. The drying procedure was similar for all specimens. They had been herbarium pressed when collected, and prior to the current analyses bryophyte specimens were freed by hand of extraneous material still adhering to the leaves by using plastic tweezers and disposable plastic gloves. Thereafter, they were washed with deionized water, oven-dried at $60^{\circ} \mathrm{C}$ to constant weight (dry weight) and ground to a fine powder in a mill.

\section{Isotope and elemental analyses}

The $\delta^{15} \mathrm{~N}$ ratios were measured on a Delta $\mathrm{C}$ mass spectrometer (Finnigan Mat, Bremen, Germany) operated in continuous flow mode after combustion of the samples in a C and N elemental analyser (NA1500, Series 1, Carlo Erba Instrumentaziones, Milan, Italy). Results of ${ }^{15} \mathrm{~N}$ natural abundance were expressed in $\delta$-values (Nadelhoffer \& Fry 1994). The $\delta^{15} \mathrm{~N}$ is expressed in parts per thousand relative to atmospheric $\mathrm{N}_{2}: \delta^{15} \mathrm{~N}=\left(R_{\text {sample }} /\right.$ $\left.R_{\text {atmosphere }}-1\right) \times 1000 \%$, in which $R_{\text {sample }}$ and $R_{\text {atmosphere }}$ are the ${ }^{15} \mathrm{~N} /{ }^{14} \mathrm{~N}$ ratios of the sample and the atmospheric $\mathrm{N}_{2}$ standard, respectively. The analytical precision was in general better than $0.2 \%$.

Leaf concentrations of $\mathrm{P}, \mathrm{K}$ and $\mathrm{S}$ were measured on subsamples (about $100 \mathrm{mg}$ ) of ground leaves. Samples were digested in a microwave Whirlpool AVM 635 using open fluorinated ethylene propylene flasks (Nalge Company, Rochester) with an acid solution of $2: 1$ nitric and $60 \%$ perchloric acids. Once samples were efficiently 
Table 1 Changes in leaf $\delta^{15} \mathrm{~N}$ and leaf $\mathrm{N}$ concentration in 24 vascular plant species collected in Spain in four different decades throughout the XX century. Values are means, with SEM in parentheses. Period values not significantly different at the $P<0.05$ level are followed by the same letter (anova followed by Tukey's test). n- number of samples

\begin{tabular}{|c|c|c|c|c|}
\hline Species & Period & $\delta^{15} \mathrm{~N}(\%)$ & N (\% DW) & $n$ \\
\hline \multirow[t]{4}{*}{ Acer opalus } & $1920-30$ & 0.97 (2.71)a & $2.53(0.01) \mathrm{a}$ & 3 \\
\hline & $1945-55$ & $-0.43(0.38) \mathrm{a}$ & $2.33(0.19) \mathrm{a}$ & 4 \\
\hline & $1960-70$ & -2.05 & 2.60 & 1 \\
\hline & 1985-95 & -2.15 & 2.01 & 1 \\
\hline \multirow[t]{3}{*}{ Arbutus unedo } & $1945-55$ & $0.70(0.92) \mathrm{a}$ & $1.76(0.09) a$ & 5 \\
\hline & $1960-70$ & -1.63 & 1.83 & 1 \\
\hline & 1985-95 & $-5.87(0.19) \mathrm{b}$ & $1.14(0.01) b$ & 8 \\
\hline \multirow[t]{3}{*}{ Borago officinalis } & $1920-30$ & $5.20(1.74) \mathrm{a}$ & $2.43(0.13) \mathrm{a}$ & 4 \\
\hline & $1945-55$ & $2.60(0.46) \mathrm{a}$ & $2.15(0.12) b$ & 4 \\
\hline & 1985-95 & $0.00(2.20) \mathrm{a}$ & $2.65(0.16) \mathrm{a}$ & 4 \\
\hline \multirow[t]{3}{*}{ Chenopodium ambrosoides } & $1920-30$ & $9.20(1.84) \mathrm{a}$ & $3.12(0.14) \mathrm{a}$ & 4 \\
\hline & $1945-55$ & $9.80(2.27) a$ & $4.70(0.56) \mathrm{b}$ & 4 \\
\hline & 1985-95 & $1.00(1.05) \mathrm{b}$ & $2.81(0.25) \mathrm{a}$ & 4 \\
\hline \multirow[t]{4}{*}{ Cistus albidus } & $1920-30$ & $1.90(0.16) a$ & $1.62(0.01) a$ & 8 \\
\hline & $1945-54$ & $0.79(0.07) \mathrm{b}$ & $1.50(0.07) \mathrm{a}$ & 8 \\
\hline & $1960-70$ & -0.22 & 0.67 & 1 \\
\hline & 1985-95 & $-4.07(0.27) \mathrm{c}$ & $1.84(0.15) \mathrm{a}$ & 6 \\
\hline \multirow[t]{4}{*}{ Erica multiflora } & $1920-30$ & 0.08 (1.96)a & $1.23(0.09) a$ & 4 \\
\hline & $1945-55$ & $4.40(0.58) \mathrm{a}$ & $1.00(0.06) \mathrm{a}$ & 3 \\
\hline & $1960-70$ & $2.67(1.82) \mathrm{a}$ & $1.24(0.57) \mathrm{a}$ & 2 \\
\hline & 1985-95 & -0.45 & 0.97 & 1 \\
\hline \multirow[t]{3}{*}{ Fagus silvatica } & $1920-30$ & $0.30(0.20) a$ & $3.79(0.06) \mathrm{a}$ & 4 \\
\hline & $1945-55$ & $-0.50(0.30) a$ & $3.22(0.16) b$ & 4 \\
\hline & 1985-95 & $-5.10(1.81) b$ & $2.95(0.14) \mathrm{b}$ & 4 \\
\hline \multirow[t]{3}{*}{ Fraxinus excelsior } & $1920-30$ & $-0.50(0.22) \mathrm{a}$ & $3.22(0.11) a, b$ & 4 \\
\hline & $1945-55$ & $-0.50(0.29) a$ & $3.00(0.13) \mathrm{a}$ & 7 \\
\hline & 1985-95 & $-0.07(0.04) \mathrm{a}$ & $3.40(0.13) b$ & 8 \\
\hline \multirow[t]{3}{*}{ Hedera helix } & $1920-30$ & 4.80 (1.84)a & $2.00(0.14) \mathrm{a}$ & 4 \\
\hline & $1945-55$ & $4.50(1.45) \mathrm{a}$ & $2.10(0.17) \mathrm{a}$ & 4 \\
\hline & 1985-95 & $2.90(0.20) a$ & $1.65(0.15) \mathrm{a}$ & 4 \\
\hline \multirow[t]{3}{*}{ Juniperus oxycedrus } & $1920-30$ & -2.90 & 1.20 & 1 \\
\hline & $1945-55$ & 1.55 (2.82)a & 0.90 & 2 \\
\hline & 1985-95 & $-4.27(0.57) \mathrm{a}$ & $1.84(0.05)$ & 3 \\
\hline \multirow[t]{3}{*}{ Laurus nobilis } & $1920-30$ & 6.50 (1.33)a & $3.39(0.57) \mathrm{a}$ & 4 \\
\hline & $1945-55$ & $1.30(0.46) \mathrm{b}$ & $3.20(0.49) \mathrm{a}$ & 4 \\
\hline & 1985-95 & $0.00(1.58) \mathrm{b}$ & $1.94(0.08) b$ & 4 \\
\hline \multirow[t]{3}{*}{ Lonicera implexa } & $1920-30$ & $0.10(0.75) \mathrm{a}$ & $1.73(0.12) a$ & 3 \\
\hline & $1945-55$ & $-1.55(2.65) a, b$ & $1.45(0.25) \mathrm{a}$ & 2 \\
\hline & 1985-95 & $-3.20(0.59) \mathrm{b}$ & $1.28(0.02) \mathrm{a}$ & 2 \\
\hline \multirow[t]{4}{*}{ Phillyrea angustifolia } & $1920-30$ & $0.15(0.75) a$ & $1.30(0.20) \mathrm{a}$ & 2 \\
\hline & $1945-55$ & $1.83(0.33) \mathrm{a}$ & $1.40(0.21) \mathrm{a}$ & 3 \\
\hline & $1960-70$ & $2.39(3.48) a, b$ & $1.46(0.37) \mathrm{a}$ & 3 \\
\hline & 1985-95 & $-5.01(0.75) b$ & $1.04(0.08) a$ & 4 \\
\hline \multirow[t]{2}{*}{ Pinus sylvestris } & $1945-55$ & -2.70 & 2.00 & 1 \\
\hline & 1985-95 & $-4.58(2.08)$ & $1.43(0.17)$ & 2 \\
\hline \multirow[t]{4}{*}{ Plantago major } & $1920-30$ & 4.20 & 1.90 & 1 \\
\hline & $1945-55$ & $6.53(3.72) a$ & $2.37(0.54) a$ & 3 \\
\hline & $1960-70$ & 0.89 & 2.27 & 1 \\
\hline & 1985-95 & $2.50(0.40) \mathrm{a}$ & $1.55(0.65) \mathrm{a}$ & 2 \\
\hline \multirow[t]{2}{*}{ Populus alba } & $1945-55$ & $4.75(0.35) \mathrm{a}$ & $3.10(0.40) \mathrm{a}$ & 2 \\
\hline & 1985-95 & $1.07(0.28) \mathrm{b}$ & $1.46(0.13) b$ & 2 \\
\hline \multirow[t]{3}{*}{ Quercus coccifera } & $1920-30$ & 4.20 & 1.40 & 1 \\
\hline & $1945-55$ & 5.90 & 1.10 & 1 \\
\hline & $1960-70$ & $-1.24(2.08)$ & $1.38(0.08)$ & 3 \\
\hline Quercus ilex & $1920-30$ & $2.32(0.23) a$ & $1.62(0.02) \mathrm{a}$ & 7 \\
\hline
\end{tabular}




\begin{tabular}{|c|c|c|c|c|}
\hline Species & Period & $\delta^{15} \mathrm{~N}(\%$ o $)$ & N (\% DW) & $n$ \\
\hline & $1945-55$ & 1.72 (0.50)a & $1.54(0.01) b$ & 10 \\
\hline & $1960-70$ & $-2.21(0.82) b$ & $1.26(0.04) \mathrm{c}$ & 4 \\
\hline & 1985-95 & $-0.57(0.13) \mathrm{b}$ & $1.71(0.02) \mathrm{d}$ & 6 \\
\hline \multirow[t]{3}{*}{ Rhamnus alaternus } & $1945-55$ & $1.00(0.38) a$ & $1.93(0.20) a$ & 3 \\
\hline & $1960-70$ & 1.02 & 1.40 & 1 \\
\hline & 1985-95 & $-2.60(0.84) b$ & $2.10(0.24) \mathrm{a}$ & 5 \\
\hline \multirow[t]{2}{*}{ Rhododendron ferrugineum } & 1945-55 & $0.18(0.66)$ & $1.38(0.08)$ & 4 \\
\hline & 1985-95 & -0.92 & 1.36 & 4 \\
\hline \multirow[t]{4}{*}{ Rosmarinus officinalis } & $1920-30$ & $0.50(3.30) a, b$ & $1.15(0.15) a, b$ & 2 \\
\hline & $1945-55$ & $3.15(0.19) \mathrm{a}$ & $1.43(0.09) \mathrm{a}$ & 4 \\
\hline & $1960-70$ & -1.98 & 0.97 & 1 \\
\hline & 1985-95 & $-1.32(1.16) b$ & $1.00(0.13) b$ & 4 \\
\hline \multirow[t]{3}{*}{ Ruscus aculeatus } & $1920-30$ & $-2.00(1.40) a$ & $1.32(0.14) \mathrm{a}$ & 4 \\
\hline & $1945-55$ & $0.50(0.22) \mathrm{a}$ & $1.94(0.22) a$ & 4 \\
\hline & 1985-95 & $2.40(0.22) b$ & $2.04(0.14) \mathrm{a}$ & 4 \\
\hline \multirow[t]{3}{*}{ Salvia officinalis } & $1920-30$ & $2.20(1.64) \mathrm{a}$ & $2.53(0.30) \mathrm{a}$ & 4 \\
\hline & $1945-55$ & $2.80(1.56) \mathrm{a}$ & $2.57(0.49) \mathrm{a}$ & 4 \\
\hline & $1985-95$ & $2.60(2.29) \mathrm{a}$ & $2.40(0.22) \mathrm{a}$ & 4 \\
\hline \multirow[t]{3}{*}{ Thymus vulgaris } & $1920-30$ & $3.30(1.30) \mathrm{a}$ & 1.70 & 2 \\
\hline & $1945-55$ & 4.35 (4.25)a & $1.40(0.10) \mathrm{a}$ & 2 \\
\hline & 1985-95 & $-0.93(1.27) \mathrm{a}$ & $1.62(0.33) \mathrm{a}$ & 2 \\
\hline
\end{tabular}

Table 2 Changes in leaf $\delta^{15} \mathrm{~N}$ and leaf $\mathrm{N}, \mathrm{P}, \mathrm{K}$ and $\mathrm{S}$ concentrations in 3 bryophyte species collected in Spain in four different decades throughout the XX century. Values are means, with SEM in parentheses. Period values not significantly different at the $P<0.005$ level are followed by the same letter (anova followed by Tukey's test). $n$, number of samples

\begin{tabular}{|c|c|c|c|c|c|c|c|}
\hline Species & Period & $\delta^{15} \mathrm{~N}(\%$ ) & N (\% DW) & $\mathrm{K}\left(\mathrm{mg} \mathrm{g}^{-1} \mathrm{DW}\right)$ & $\mathrm{P}\left(\mathrm{mg} \mathrm{g}^{-1} \mathrm{DW}\right)$ & $\mathrm{S}\left(\mathrm{mg} \mathrm{g}^{-1} \mathrm{DW}\right)$ & $n$ \\
\hline \multirow[t]{4}{*}{ Hypnum cupressiforme } & $1920-30$ & $4.72(4.50) a$ & $0.96(0.19) \mathrm{a}$ & $1.83(0.69) \mathrm{a}$ & $0.37(0.08) \mathrm{a}$ & $0.80(0.24) \mathrm{a}$ & 6 \\
\hline & $1945-55$ & $4.40(1.28) a$ & $0.98(0.08) a$ & $1.98(0.43) a$ & $0.42(0.08) \mathrm{a}$ & $0.73(0.08) a$ & 6 \\
\hline & $1960-75$ & $3.40(2.43) \mathrm{a}$ & $0.98(0.13) \mathrm{a}$ & $3.58(0.37) b$ & $0.50(0.06) \mathrm{b}$ & $0.95(0.07) a$ & 6 \\
\hline & $1985-90$ & $2.38(1.61) a$ & $1.12(0.09) \mathrm{a}$ & $4.46(0.54) b$ & $1.13(0.15) b$ & $0.99(0.14) a$ & 9 \\
\hline \multirow[t]{3}{*}{ Pleurochaete squarrosa } & $1945-55$ & $1.47(0.35) \mathrm{a}$ & $1.10(0.12) \mathrm{a}$ & $1.80(0.22) \mathrm{a}$ & $0.48(0.08) \mathrm{a}$ & $0.93(0.04) \mathrm{a}$ & 5 \\
\hline & $1960-75$ & $-0.60(2.68) a$ & $1.19(0.17) \mathrm{a}$ & $3.54(0.73) a, b$ & $0.58(0.18) a$ & $1.22(0.18) a$ & 7 \\
\hline & $1985-90$ & $-3.11(1.89) a$ & $1.52(0.14) \mathrm{a}$ & $3.34(0.18) b$ & $0.79(0.19) a$ & $1.52(0.27) a$ & 6 \\
\hline \multirow[t]{3}{*}{ Grimmia laevigata } & $1945-55$ & $-0.25(0.53) a$ & $1.55(0.06) \mathrm{a}$ & $3.00(0.09) \mathrm{a}$ & $0.74(0.10) a$ & $1.10(0.04) \mathrm{a}$ & 4 \\
\hline & $1960-75$ & $-1.65(1.89) \mathrm{a}$ & $1.25(0.26) \mathrm{a}$ & $4.00(0.99) a, b$ & $0.66(0.11) \mathrm{a}$ & $1.29(0.25) a, b$ & 4 \\
\hline & 1985-90 & 1.77 (1.37)a & $1.33(0.12) \mathrm{a}$ & $6.16(1.32) b$ & $1.00(0.04) b$ & $1.62(0.07) b$ & 4 \\
\hline
\end{tabular}

oxidized $\left(0.5 \mathrm{~cm}^{3}\right.$ remaining), they were diluted with $20 \mathrm{~mL}$ of $3 \%$ perchloric acid. Flasks were stoppered and shaken by hand for thorough mixing of the contents. The sample solution was poured into a polystyrene sample cuvette, placed in an autosampler carousel and analysed for the above mentioned elements by ICAP-AES (inductively coupled argon plasma emission spectrometer) Polyscan Thermo Jarrel ASH Model 61 E (Peñuelas \& Matamala 1993). Quality control was ensured by taking a reference sample (Pine needles, NIST 1575) after every 10 samples analysed. Readings were accepted when reference samples were within a 5\% range of known values.

\section{Statistics}

Statistical analyses were conducted using a one-way anova with sampling decade as the main effect and using the Tukey's significant difference at 0.05 level between species means for the periods 1920-30, 1940-50, 1960-70 and 1985-95, after testing for normality and homogeneity 


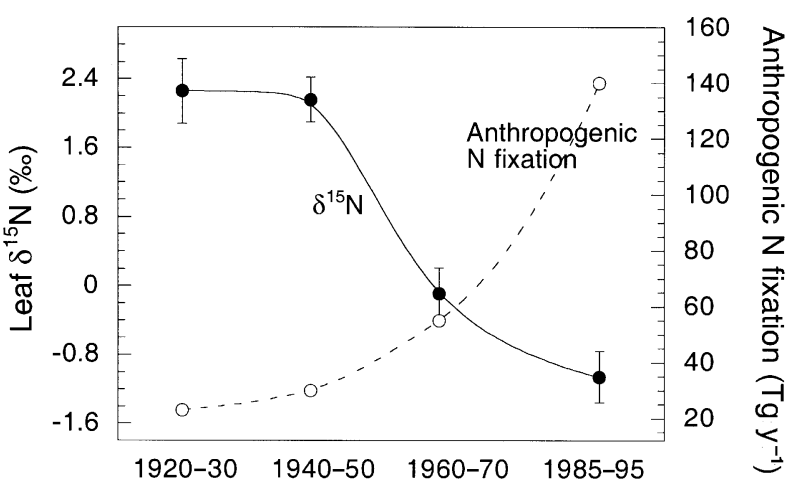

Fig. 1 Trend of the leaf $\delta^{15} \mathrm{~N}$ overall average for 27 plant species collected in Spain in four different decades throughout the $\mathrm{XX}$ century. It is depicted together with the trend of global anthropogenic $\mathrm{N}$ fixation (Vitousek 1994). Bars indicate \pm SE. $n=27$ species mean values. One to 10 herbarium specimens were analysed per decade and species (Table 1 ).

of variance. Regression models of the studied variables across the decades were conducted with the species mean values, and therefore with values of known associated variance. Thus, as a model I regression was not strictly appropriate, a model II regression with the reduced major axis method was used (Sokal \& Rohlf 1995). Statistical analyses were conducted using the statistical program package SYSTAT 5.2 (SYSTAT Inc., Evanston, IL)

\section{Results and discussion}

The overall species $\delta^{15} \mathrm{~N}$ values decreased consistently from $2.26 \%$ in $1920-30$ and 2.16 in $1940-50$, to $-0.09 \%$ in $1960-70$, and to $-1.06 \%$ in 1985-95 (Fig. 1). As widely recognised (Handley \& Scrimgeour 1997), many environmental and geographical factors affect foliar ${ }^{15} \mathrm{~N}$ abundance, but this strong ${ }^{15} \mathrm{~N}$ signal provides, at least, a clear indication of an altered $\mathrm{N}$ cycle in Spanish ecosystems. The decreasing pattern was general in almost all species without significant differences between vascular plants and bryophytes (Tables 1 and 2). This pattern is strikingly coincident with the pattern for nitrate $\delta^{15} \mathrm{~N}$ in alpine and polar ice cores (Freyer et al. 1996), and it is also in agreement with preliminary herbarium studies (Peñuelas \& Estiarte 1997). It confirmed our hypothesis: nitrogen used by plants is becoming poorer in ${ }^{15} \mathrm{~N}$. These results indicate that increasing nitrogen inputs in Spanish terrestrial ecosystems are in accord with increasing $\mathrm{N}$ emissions from increased fossil fuel combustion and livestock production in the region (Anonymous 1991) and in the globe (Vitousek 1994). They also suggest a predominance of these inputs over outputs because otherwise the latter (denitrification, ammonia volatilization, and nitrate leaching) would have caused a $\delta^{15} \mathrm{~N}$ enrichment of the remaining available nitrogen (Högberg et al. 1995). This predominance of inputs over outputs has been confirmed with actual measurements of atmospherically deposited $\mathrm{N}$ being retained within these Mediterranean ecosystems (Avila et al. 1999; Rodà et al. 2000).

The present results provide an interesting contrast with some studies in Sweden (Näsholm et al. 1997) and the USA (Garten 1993), where the $\delta^{15} \mathrm{~N}$ signatures of foliage have been observed to increase rather than decrease with $\mathrm{N}$ availability. As fractionation during uptake seems greater when $\mathrm{N}$ is not limiting growth (Högberg et al. 1999), larger fractionation during uptake, as a consequence of the increased availability of $\mathrm{N}$, may have been present in those northern ecosystems. $\mathrm{N}$ supply rate to Spanish terrestrial ecosystems is still low in relation to plant demand, in contrast with those coldtemperature ecosystems, as indicated by low $\mathrm{N}$ losses in streamwater $\left(<0.1 \mathrm{kgN} \mathrm{ha} \mathrm{h}^{-1}\right.$, Avila etal. 1999). Moreover, Mediterranean ecosystems have drier soils and are more dependent on the atmospheric $\mathrm{N}$ component than cold-temperate ecosystems. Atmospheric N supply has been calculated to represent a very high proportion (36-53\%) of the $\mathrm{N}$ incorporated into biomass in Mediterranean ecosystems of NE Spain (Rodà et al. 2000). Other possible explanations for these contrasting results between Northern and Mediterranean ecosystems are less plausible. For example, a different relative importance of ammonium (usually ${ }^{15} \mathrm{~N}$ enriched: Garten 1992; Koopmans et al. 1997) and nitrate (usually ${ }^{15} \mathrm{~N}$ depleted: Garten 1992; Koopmans et al. 1997) in deposition can be discarded because there were no clear differences between Spain (Rodà etal. 2000) and these other countries (Garten 1993; Koopmans etal. 1997; Näsholm etal. 1997) in the relative contribution of ammonium and nitrate to total precipitation. Moreover, both positive and negative values for precipitation ammonium-N have been reported (Garten 1993; Koopmans et al. 1997)

There are also other factors influencing plant $\delta^{15} \mathrm{~N}$ such as ecosystem water availability (Handley et al. 1999), but the drier conditions of the last decades in NE Spain (Piñol et al. 1998) would have had to induce a reverse trend to the one found here. In fact, leaf $\delta^{15} \mathrm{~N}$ values have been found to increase in NE Spain Mediterranean ecosystems in response to recent droughts (Peñuelas et al. 2000). The most likely explanation of this strong ${ }^{15} \mathrm{~N}$ signal seems thus to be an increased predominance of $\mathrm{N}$ inputs over outputs.

Leaf $\mathrm{N}$ concentrations of vascular plants decreased in the second half of the century (Fig. 2) as expected from the increased atmospheric $\mathrm{CO}_{2}$ concentrations and greater C availability (McGuire etal. 1995), and also in 


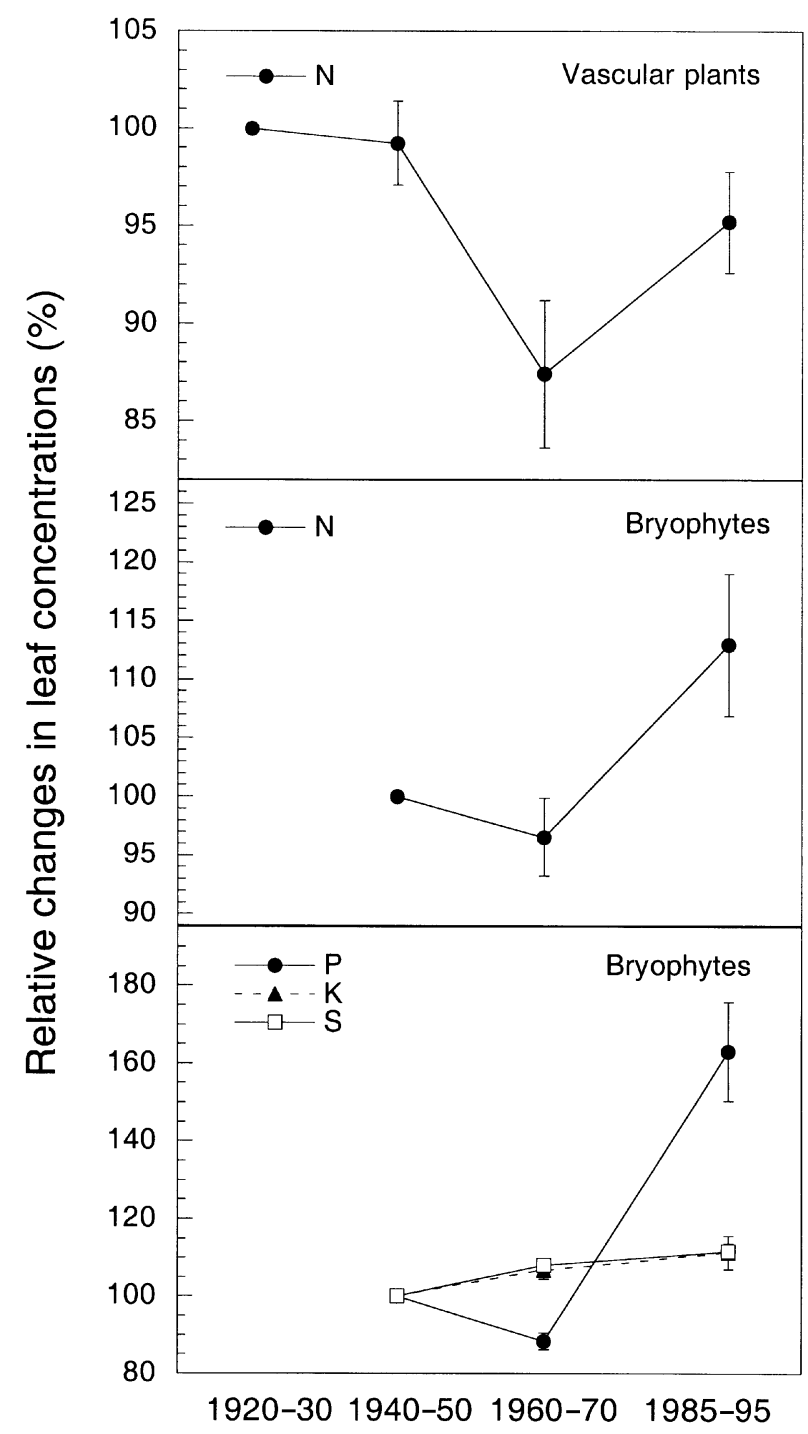

Fig. 2 Relative changes in the overall leaf concentration of $\mathrm{N}$ in vascular plants and of $\mathrm{N}, \mathrm{P}, \mathrm{K}$ and $\mathrm{S}$ in bryophytes collected in Spain in four different decades throughout the XX century. The values are relative to the $1920-30$ species average values in vascular plants and to the $1940-50$ species average values in bryophytes. Bars indicate \pm SE. In vascular plants $n=24$ species mean values 1-10 herbarium specimens were analysed per decade and species). In bryophytes $n=3$ species mean values (4-9 herbarium specimens analysed per decade and species, Table 2).

agreement with our previous herbarium studies (Peñuelas \& Matamala 1990). However, there was a slight trend towards recovery. Coinciding with the increase in anthropogenic $\mathrm{N}$ inputs (Anonymous 1991 and Fig. 1) there was a $9 \%$ increase in $\mathrm{N}$ concentrations in 1985-95 relative to $1960-70$ (Fig. 2). Bryophyte species, which are more exposed to the direct effects of atmospheric $\mathrm{N}$ inputs, were also found to have increased $\mathrm{N}$ concentrations (1985-95 concentrations were 17\% higher than in 1960-70; Fig. 2). Changes relative to 1920-30 values for each species of vascular plant and to 1940-50 values for each species of bryophyte were used in the data analyses to standardize the variability resulting from species genetic differences and to focus on the environmental variability.

In bryophytes $\mathrm{P}, \mathrm{K}$, and $\mathrm{S}$ concentrations in 1985-95 were $65 \%, 13 \%$, and $12 \%$ higher than in 1940-50 (Fig. 2, Table 2), providing furhter evidence of increasing general eutrophication of Spanish terrestrial ecosystems. However, the concentrations of these nutrients in vascular plants did not present any clear pattern (data not shown), probably because they are less sensitive than bryophytes to aerial deposition, and their nutrient uptake and mobilization is more complexly regulated.

Human alteration of nutrient cycles represents an ongoing global change and the plant chemical changes presented here provide new evidence for this alteration. They indicate that added anthropic $\mathrm{N}$ and nutrients are retained, at least in part, in the terrestrial ecosystems of rural regions of Spain which, although not pristine, are not near to very highly industrialized or urbanized areas. Profound consequences may be foreseen for ecological processes at all levels of organization, from organism to global levels, including, for example, effects on community biodiversity, vegetation distribution, or even on enhanced carbon sink (Vitousek etal. 1997). This increased eutrophication could be partly responsible of the global increase in biospheric activity inferred from the increase in the amplitude of the atmospheric $\mathrm{CO}_{2}$ annual oscillation during the period 1960-94 (Keeling et al. 1996).

\section{Acknowledgements}

We thank J. Vallés, M. Brugués and 'Unitats de Botànica de la Facultat de Farmàcia de la Universitat de Barcelona i de la Facultat de Ciències de la Universitat Autònoma de Barcelona' for supplying the herbarium specimens, P. Teixidor and Serveis Científico Tècnics de la Universitat de Barcelona for technical assistance with the isotope and the ICAP analyses, and J. Terradas, F. Rodà and F. Lloret and A. Avila for comments on the manuscript. The research was funded by CICYT CLI19990479 (Spanish Government), DURSI- DMA IMMPACTE (Catalan Government) and Fundació Territori i Paisatge.

\section{References}

Anonymous (1991) La contaminació atmosferica. Factors meteorològics, contaminants $i$ efectes de la contaminació atmosferica. Generalitat de Catalunya, Departament de Política Territorial i Obres Públiques, Barcelona.

Avila A, Bellot J, Piñol J (1999) Element budgets in catchments. In: Ecology of Mediterranean Evergreen Oak Forests (eds Rodà $\mathrm{F}$ et al.), pp. 283-296. Springer, Berlin.

Crutzen PJ, Andreae MO (1990) Biomass burning in the tropics: 
impact on atmospheric chemistry and biogeochemical cycles. Science, 250, 1669-1678.

European Environment Agency (1998). Europe's Environment: the Second Assessment. Elsevier, Oxford.

Freyer HD, Kobel K, Delmas RJ, Kley D, Legrand MR (1996) First results of ${ }^{15} \mathrm{~N} /{ }^{14} \mathrm{~N}$ ratios in nitrate from alpine and polar ice cores. Tellus, 48B, 93-105.

Garten CT Jr (1992) Nitrogen isotope composition of ammonium and nitrate in bulk precipitation and forest throughfall. International Journal of Environmental Analytical Chemistry, 47, 33-45.

Garten CT Jr (1993) Variation in foliar ${ }^{15} \mathrm{~N}$ abundance and the availability of soil nitrogen on Walker Branch watershed. Ecology, 74, 2098-2113.

Handley LL, Austin AT, Robinson D etal. (1999) The ${ }^{15} \mathrm{~N}$ abundance $\left(\delta^{15} \mathrm{~N}\right)$ of ecosystem samples reflects measures of water availability. Australian Journal of Plant Physiology, 26, 185-199.

Handley LL, Scrimgeour CM (1997) Terrestrial plant ecology and ${ }^{15} \mathrm{~N}$ natural abundance: the present limits to interpretation for uncultivated systems with original data from a Scottish old field. Advances in Ecological Research, 27, 133-212.

Högberg P, Johannisson C, Högberg M, Högbom L, Näsholm T, Hällgren JE (1995) Measurements of abundances of ${ }^{15} \mathrm{~N}$ and ${ }^{13} \mathrm{C}$ as tools in retrospective studies of $\mathrm{N}$ balances and water stress in forests: a discussion of preliminary results. Plant and Soil, 168-169, 125-133.

Högberg P, Högberg M, Högbom L, Quist ME, Ekbland A, Näsholm T (1999) Nitrogen isotope fractionation during nitrogen uptake by ectomycorrhizal and non-mycorrhyzal Pinus sylvestris. New Phytologist, 142, 569-576.

Jones K, Jackson A, Johnston AE (1992) Evidence for an increase in the cadmium content of herbage since the 1860s. Environmental Science and Technology, 26, 834-836.

Keeling CD, Chin JFS, Whorf TP (1996) Increased activity of northern vegetation inferred from atmospheric $\mathrm{CO}_{2}$ measurements. Nature, 382, 146-149.

Koopmans CJ, van Dam D, Tietema A, Verstraten JM (1997) Natural ${ }^{15} \mathrm{~N}$ abundance in two nitrogen saturated forest ecosystems. Oecologia, 111, 470-480.

Markert B (1993) Plants as Biomonitors-Indicators for Heavy Metals in the Terrestrial Environment. VCH Verlagsgesellchaft, Weinheim.

McGuire AD, Melillo JM, Joyce LA (1995) The role of nitrogen in the response of forest net primary production to elevated atmospheric carbon dioxide. Annual Review of Ecology and Systematics, 26, 473-503.

Melillo JM, McGuire AD, Kicklighter DW, Moore B, Vorosmarty CJ, Schloss AL (1993) Global climate change and terrestrial net primary production. Nature, 363, 234-240.

Monaci F, Bargagli R (1997) Barium and other trace metals as indicators of vehicle emissions. Water, Air and Soil Pollution, 110, 89-98.

Nadelhoffer KJ, Fry B (1994) In: Stable Isotopes in Ecology and Environmental Science (eds Lajtha K, Michener RH), pp. 22-44. Blackwell Scientific Publications, Oxford.

Näsholm T, Nordin A, Edfast AB, Högberg P (1997) Identification of coniferous forests with incipient nitrogen saturation through analysis of arginine and nitrogen-15 abundance of trees. Journal of Environmental Quality, 26, 302309.

Peñuelas J, Estiarte M (1997) Trends in carbon plant concentration and plant demand of $\mathrm{N}$ throughout this century. Oecologia, 109, 69-73.

Peñuelas J, Matamala R (1990) Changes in N and S leaf content, stomatal density and specific leaf area of 14 plant species during the last three centuries of $\mathrm{CO}_{2}$ increase. Journal of Experimental Botany, 41, 1119-1124.

Peñuelas J, Matamala R (1993) Variations in the mineral composition of herbarium plant species collected during the last three centuries. Journal of Experimental Botany, 44, 15231525.

Peñuelas J, Filella I, Lloret F, Piñol J, Siscart D (2000) Effects of a severe drought on water and nitrogen use by Quercus ilex and Phillyrea latifolia. Biologia Plantarum, 43, 47-53.

Piñol J, Terrades J, Lloret F (1998) Climate warming, wildfire hazard, and wildfire occurrence in coastal eastern Spain. Climatic Change, 38, 345-357.

Rodà F, Avila A, Rodrigo A (2000) Nitrogen deposition in Mediterranean forests. Environmental Pollution, in press.

Rühling A (1994) Atmospheric Heavy Metal Deposition in EuropeEstimations Based on Moss Analysis. Nordic Council of Ministers, Nord, 9, 1-53.

Sokal RR, Rohlf FJ (1995) Biometry: The Principles and Practice of Statistics in Biological Research, 3rd edn. WH Freeman, New York.

Vitousek P (1994) Beyond global warming: ecology and global change. Ecology, 75, 1861-1876.

Vitousek PM, Aber JD, Howarth RW etal. (1997) Human alteration of the global nitrogen cycle: sources and consequences. Ecological Applications, 7, 737-750. 